\title{
Effect of Bagging Type on Reducing Pomegranate Fruit Disorders and Quality Improvement
}

\author{
M. Abou El-Wafa \\ Olive \& Semi-arid Zone Fruits Research Department, \\ Horticulture Research Institute, Agricultural Research Centre, \\ Cairo, Egypt.
}

\begin{abstract}
THE PRESENT investigation was carried out in a private farm located at Alexandria desert road, El-Behira Governorate, Egypt to study the effect of bagging type on reducing pomegranate fruit disorders and improving fruit quality during 2011 and 2012 seasons. The bagging treatments were, brown paper bag, white paper bag, prgmen bag, agrail white bag, agrail red bag, agrail blue bag and plastic bag. The treatments started at 21 days after fruit set and sustained till harvest time. The obtained results showed that, bagging fruits with prgmen bag increased fruit length, fruit diameter, grain weight percentage, fruit weight $(\mathrm{g})$, yield/tree $(\mathrm{kg})$, TSS \%, total soluble sugars, vitamin $\mathrm{C}$ content and total anthocyanin content in fruit juice. While, the percentage of cracked fruits, sunburn fruits /tree and fruit mechanical damage were reduced as compared to the other treatments. On the other hand, bagged fruits with plastic bags increased peel weight percentage and total acidity percentage. Moreover, bagging with agrail blue bag had a significant effect on increasing values of lightness (L) .While, bagging with prgmen bag had a significant effect on higher values of lightness (L) and redness (a) compared to the other treatments. Generally, it can be recommended from this study that, bagging pomegranate fruits with prgmen bags was the best in reducing fruit disorders with improving fruit quality as well as increasing the net profit for farmer.
\end{abstract}

Keywords: Pomegranate, Wonderful, Bagging, Fruit quality.

Pomegranate cultivation area in Egypt has been rapidly increased almost three times from 13521 in 2011 to $34.450 \mathrm{Fed}$. in 2013. Consequently, the production increased from 64574 to106.260 Ton. The reason can be due to the fact that pomegranate is a highly profitable fruit crop in addition to its adaptability to grow in a wide range of climate ranging from temperate to subtropical. Many industrials are based on its fruits such as pomegranate juice, conserve, vinegar, citric acid and medicine, which enrich pomegranate fruits in the world market (Aviram and Dornfeld, 2001).Currently, there is a greater interest in pomegranate juice due to its high antioxidant activity (Gil et al., 2000). Pomegranates are mainly grown for fresh consumption of arils or juice, although in various countries they are produced for syrup, jams carbonated beverages or wine and beverage industry as flavoring and coloring agents (Maestre et al., 2000 and Kader, 2006). The Wonderful variety of pomegranate, grown extensively in 
California, has become popular as a commercial juice with potential health benefits. The fruit is round but flattened at the poles, very large, dark purple-red, with medium-thick rind, deep-red, juicy, winey pulp and medium-hard seeds. Plant is vigorous and productive, large purple red fruit, best quality in hot inland climate, long-lived in any soil, bears in the first year of planting and self-fertile (LaRue, 1980). Nowadays, the Wonderful variety is growing extensively in Egypt, especially in the newly reclaimed areas. However, due to the high temperature and sunlight in Egypt, the fruits exposed to certain mechanical and physiological disorders which reduce the fruit quality and marketability. In this respect, the process of fruit bagging is a necessary to protect from direct sun light, mechanical damage and worm pomegranates. Regardless, the high cost of the bagging process but the fruit quality improvement compensates this cost in particular when the fruits are exported. Bagging is a physical protection technique commonly applied to many fruits. It can, not only, protect the fruit from diseases and pests, but also, change the microenvironment of fruit development, which exerts multiple effects on the growth and quality of fruits (Guzman, 2004, Thorp et al., 2007, Son \& Lee, 2008 and Li et al., 2008). Bagging protects fruit from diseases, pests and produce high quality unblemished fruits (Kitagawa et al., 1992). Fruit pre-harvest bagging could effectively improve fruit coloration, markedly lower pesticide residual and avoid eating by birds and insects (Hu et al., 2001 and Jia et al., 2005). Bagging peach fruits during maturation can improve fruit quality through reducing diseases and modifying fruit microenvironment (Hofman et al., 1997). Yang et al., (2009) proved that bagging could modify the microenvironment during fruit development, decreasing the rate of fruit drop and has been widely used to improve fruit appearance, decrease pesticide residues and increase commercial fruit value. Moreover, bagged fruits are preferred by the consumers. The fruit bagging technique is widely adopted in the production of apple, pear, grapefruit, litchi, longan and other fruits, for improving fruit quality and effectively reducing pesticide residues, preventing from rust, decreasing rates of insect or disease damaged and fruit cracking (Fallahi et al., 2001, Wang, et al., 2003, Xin \& Zhang, 2003, Jia et al., 2005, Wei, et al., 2005, Wei et al., 2011 and Hudina et al., 2012). Generally, bagging treatments improves fruit appearance, protects fruit against damage from insect, pests, birds, diseases, mechanical scratches, and also alters the microenvironment for fruit development, with multiple effects on its inner quality.

Therefore, the aim of the present experiment was to study the effect of bagging type on Wonderful pomegranate fruit quality under Egyptian conditions.

\section{Material and Methods}

The present study was carried out during 2011 and 2012 seasons on pomegranate (Punica granatum L.)Wonderful cv., the experimental trees were uniform, 4 -year- old growing in sandy soil under drip irrigation system in a private farm located at Alexandria desert road, El-Behira Governorate, Egypt. Trees were planted at a distance $5 \times 3$ meters apart and subjected to the same 
agriculture practices. The experimental trees were subjected to the following treatments:

- Control (without bagging)

- Brown paper bag

- White paper bag

- Prgmen bag

- Agrail white bag

- Agrail red bag

- Agrail blue bag

- Plastic bag

The size of all bag types, under this study, was $(25 \times 30 \mathrm{~cm})$. Twenty-four trees were selected, 3 trees per each treatment, in both seasons. All trees had the same number of bagged fruits $(50 \& 60$ fruits/tree in the first and second seasons, respectively. Bagging treatments began at 21 days after fruit set and continued until harvest (first week of October).

Field observations and laboratory measurements were carried out as follows:

Fruit physical characteristics

A sample of ten ripped fruits was randomly harvested/replicate for determining the following:

- Average fruit length $(\mathrm{cm})$ and fruit diameter $(\mathrm{cm})$.

- Percentage of grain weight (edible part) and peel weight (non-edible part) of total fruit weight.

- Total yield/tree $(\mathrm{kg})$ and fruit weight $(\mathrm{g})$.

- Percentage of cracked fruits, fruit sunburn/tree and marketable fruits/tree was calculated.

- Mechanical damaged fruit status was determined by vision.

- Fruit firmness was determined using Shatilon's instrument for measuring firmness of pomegranate. Pomegranate firmness was measured as $\left(\mathrm{g} / \mathrm{cm}^{2}\right)$.

- (L, a and b) colour was determined using a Minolta CR-300 colorimeter. Lightness, and fruit skin colour were measured on the most colored part of fruit using a colorimeter (CR-400, Minolta, Japan), which provided CIE L*, $a^{*}$ and $b^{*}$ value. $L^{*}$ represents the relative lightness of color with a range from 0 to 100 , being small for dark color and large for light color. Both $a^{*}$ and $b^{*}$ scales extend from 60 to 60 . Negative $a^{*}$ value indicates greenness and positive for redness, while $b^{*}$ is negative for blueness and positive for yellowness (McGuire, 1992).

Fruit juice chemical composition

- Total soluble solids percentage (TSS \%) was determined using hand refractometer.

- Total acidity percentage was determined by titrating $5 \mathrm{ml}$ juice against 0.1 $\mathrm{NaOH}$ using phenolphthalene as an indicator. The values of total acidity were

Egypt. J. Hort. Vol. 41, No.2 (2014) 
expressed in grams of citric acid per $100 \mathrm{ml}$ juice as described in (A.O.A.C., 1985), then, T.S.S/acid ratio was calculated.

- Total soluble sugars, were determined calorimetrically in a sample of $5 \mathrm{ml}$ juice, according to the method described by Dubois et al. (1956). The amount of estimated sugars in each sample was calculated in terms of glucose.

- Vitamin (C) content (mg. Ascorbic acid/ $100 \mathrm{ml}$ juice) according to (A. O. A. C., 1985) was measured.

- Total anthocyanin content (\%) in fruit juice as described by Hsia et al. (1965).

\section{Economical evaluation}

Economical evaluation was calculated according to: The economic evaluation, at the end of the second season, the economic evaluation was done according to the national market prices of all the production inputs and outputs.

Cost of bagging/fed $=$ cost of each bag according to the market price

- The cost of fruit bagging process/fed $=(8$ workers/fed $\times 60$ LE $)$

- The cost of fruits worm control $=($ cost of spraying pesticide/fed $)$

- Total cost $=$ The sum of all costs

- Value of $\mathrm{kg}$ fruit $(\mathrm{LE})=$ according to fruit quality

- Total income $(\mathrm{LE}) / \mathrm{fed}=($ ton/fed) $\mathrm{x}$ price/ton $(\mathrm{LE})$

- Net profit $(\mathrm{LE})=$ Total income-total cost

Statistical analysis

All data were tested for treatments effects on analyzed parameters by the oneway analysis of variance (ANOVA). Difference between treatments were compared by Duncan's Multiple Range Test (Duncan, 1955), according to Snedecor and Cochran (1980).

\section{Results and Discussion}

\section{Fruit physical characteristics}

The obtained results Table 1 indicated that, fruit length $(\mathrm{cm})$ and fruit diameter $(\mathrm{cm})$ increased significantly when used prgmen bag or un-bagged (control). While, the lowest values of fruit length $(\mathrm{cm})$ and fruit diameter $(\mathrm{cm})$ were obtained from bagging fruit with plastic bag in both seasons. Bagging treatments promoted fruit development and increased fruit size due to temperature and perhaps humidity increase around fruit. The reduction in fruit length and diameter when using plastic bags may be due to the increments in water vapor within plastic bag. These results agree with that obtained by (Johns and Scott, 1989) on banana bunches sealed within polyethylene bags. Also, all bag types promoted fruit development and increased fruit size (Tombesi et al., 1993 and Wei et al., 2009). Moreover, Abd El-Rhman, 2010 found that, bagging pomegranate fruit gave higher positive effect on fruit length and fruit diameter as compared with the control. 
TABLE 1. Effect of bagging type on fruit length $(\mathrm{cm})$ and diameter $(\mathrm{cm})$ during 2011 \& 2012 seasons.

\begin{tabular}{|c|c|c|c|c|c|c|c|c|}
\hline \multirow{3}{*}{$\begin{array}{l}\text { Treatments } \\
\text { Control } \\
\end{array}$} & \multicolumn{4}{|c|}{ Fruit length $(\mathrm{cm})$} & \multicolumn{4}{|c|}{ Fruit diameter (cm) } \\
\hline & \multicolumn{2}{|c|}{2011} & \multicolumn{2}{|c|}{2012} & \multicolumn{2}{|c|}{2011} & \multicolumn{2}{|c|}{2012} \\
\hline & 8.33 & $\mathrm{~b}$ & 8.69 & $\mathrm{a}$ & 8.05 & $\mathrm{a}$ & 8.16 & $\mathrm{ab}$ \\
\hline Brown paper bag & 7.88 & $\mathrm{c}$ & 7.23 & $\mathrm{~b}$ & 7.89 & $\mathrm{a}$ & 7.23 & $\mathrm{c}$ \\
\hline White paper bag & 7.66 & $\mathrm{~cd}$ & 7.46 & $\mathrm{~b}$ & 7.48 & $\mathrm{~b}$ & 7.45 & $\mathrm{bc}$ \\
\hline Prgmen bag & 8.80 & $\mathrm{a}$ & 7.88 & $\mathrm{~b}$ & 7.83 & $\mathrm{a}$ & 8.40 & $\mathrm{a}$ \\
\hline Agrail white bag & 7.75 & $\mathrm{~cd}$ & 7.36 & $\mathrm{~b}$ & 7.55 & $\mathrm{~b}$ & 7.53 & bc \\
\hline Agrail red bag & 7.89 & $\mathrm{c}$ & 7.22 & $\mathrm{~b}$ & 7.42 & $\mathrm{bc}$ & 7.16 & $\mathrm{c}$ \\
\hline Agrail blue bag & 7.83 & $\mathrm{c}$ & 7.56 & $\mathrm{~b}$ & 7.19 & $\mathrm{c}$ & 7.10 & $\mathrm{c}$ \\
\hline Plastic bag & 7.50 & $\mathrm{~d}$ & 6.50 & $\mathrm{c}$ & 6.83 & $\mathrm{~d}$ & 6.96 & $\mathrm{c}$ \\
\hline
\end{tabular}

Values have the same letter are not significantly different at 5\% using Duncan's Test.

Table 2, showed that un-bagged fruit had the most significant effect on increasing fruit arils (edible part \%) compared to all bagging fruit treatments. Meanwhile, bagged fruits with prgmen exceed other types of bags on increasing fruit edible part $(\%)$. However, values of fruit (non-edible part) percentage have inversely effect. In this concern, bagging with plastic bag was the superior in increasing peel weight (non-edible part \%) in both seasons.

TABLE 2. Effect of bagging type on fruit (edible part) $(\%)$ and fruit (non-edible part) (\%) during $2011 \& 2012$ seasons.

\begin{tabular}{|c|c|c|c|c|c|c|c|c|}
\hline \multirow{2}{*}{ Treatments } & \multicolumn{4}{|c|}{ Fruit (edible part) (\%) } & \multicolumn{4}{|c|}{ Fruit (non-edible part) (\%) } \\
\hline & \multicolumn{2}{|c|}{2011} & \multicolumn{2}{|c|}{2012} & \multicolumn{2}{|c|}{2011} & \multicolumn{2}{|c|}{2012} \\
\hline Control & 54.00 & $\mathrm{a}$ & 55.00 & $\mathrm{a}$ & 46.00 & $\mathrm{f}$ & 45.00 & $\mathrm{f}$ \\
\hline Brown paper bag & 49.79 & $\mathrm{c}$ & 50.00 & $\mathrm{c}$ & 50.21 & $\mathrm{~d}$ & 50.00 & $\mathrm{~d}$ \\
\hline White paper bag & 47.00 & $\mathrm{~d}$ & 48.00 & $\mathrm{~d}$ & 53.00 & $\mathrm{c}$ & 52.00 & $\mathrm{c}$ \\
\hline Prgmen bag & 53.00 & $\mathrm{~b}$ & 53.00 & $\mathrm{~b}$ & 47.00 & $\mathrm{e}$ & 47.00 & $\mathrm{e}$ \\
\hline Agrail white bag & 45.03 & $\mathrm{e}$ & 48.00 & $\mathrm{~d}$ & 54.97 & $\mathrm{~b}$ & 52.00 & $\mathrm{c}$ \\
\hline Agrail red bag & 49.28 & $\mathrm{c}$ & 48.00 & $\mathrm{~d}$ & 50.72 & $\mathrm{~d}$ & 52.00 & $\mathrm{c}$ \\
\hline Agrail blue bag & 45.53 & $\mathrm{e}$ & 46.00 & $\mathrm{e}$ & 54.47 & $\mathrm{~b}$ & 54.00 & $\mathrm{~b}$ \\
\hline Plastic bag & 42.72 & $\mathrm{f}$ & 43.00 & $\mathrm{f}$ & 57.28 & $\mathrm{a}$ & 57.00 & $\mathrm{a}$ \\
\hline
\end{tabular}

Values have the same letter are not significantly different at 5\% level using Duncan's Test.

In both seasons, the results, Table 3, clearly showed that, both un-bagged fruits (control) and bagged fruits with prgmen bag followed by white paper bag were significantly the most effective compared to the other treatments. While, the lowest values of fruit weight $(\mathrm{g})$ and yield $(\mathrm{kg})$ were obtained from bagging with Plastic bag. Increasing fruit weight may be due to such fruits are exposed to sufficient lighting density in such treatments. These results are in full agreement with those obtained by Abd El-Rhman, (2010), who reported that, the bagging pomegranate fruits gave higher weight compared with the control. Also, all bag types tended to increase fruit weight (Yang, et al., 2009). Bunch bagging increased bunch weight compared to the control (Mohamed et al., 2012). Bagging of

Egypt. J. Hort. Vol. 41, No.2 (2014) 
different fruits during development can improve yields (Kitagawa et al., 1992). On the other hand, bagging fruits reduced fruit weight of apple at harvest (Witney et al., 1991).

TABLE 3. Effect of bagging type on fruit weight (g) and fruit yield/tree (kg.) during 2011 \& 2012 seasons.

\begin{tabular}{|c|c|c|c|c|c|c|c|c|}
\hline \multirow{3}{*}{$\begin{array}{l}\text { Treatments } \\
\mathrm{ol}\end{array}$} & \multicolumn{4}{|c|}{ Fruit weight (g) } & \multicolumn{4}{|c|}{ Fruit yield/tree (kg.) } \\
\hline & \multicolumn{2}{|c|}{2011} & \multicolumn{2}{|c|}{2012} & \multicolumn{2}{|c|}{2011} & \multicolumn{2}{|c|}{2012} \\
\hline & 375.0 & $\mathrm{a}$ & 341.8 & $\mathrm{~b}$ & 18.75 & $\mathrm{a}$ & 20.51 & $\mathrm{~b}$ \\
\hline Brown paper bag & 331.3 & $\mathrm{c}$ & 327.7 & $\mathrm{c}$ & 16.56 & $\mathrm{c}$ & 19.66 & $\mathrm{c}$ \\
\hline White paper bag & 359.3 & $\mathrm{~b}$ & 303.4 & $\mathrm{~d}$ & 17.96 & $\mathrm{~b}$ & 18.21 & $\mathrm{~d}$ \\
\hline Prgmen bag & 361.0 & $\mathrm{~b}$ & 354.8 & $\mathrm{a}$ & 18.05 & $\mathrm{~b}$ & 21.29 & $\mathrm{a}$ \\
\hline Agrail white bag & 293.0 & $\mathrm{e}$ & 257.6 & $\mathrm{~g}$ & 14.65 & e & 15.46 & $\mathrm{~g}$ \\
\hline Agrail red bag & 298.9 & $\mathrm{~d}$ & 276.7 & $\mathrm{f}$ & 14.94 & $\mathrm{~d}$ & 16.60 & $\mathrm{f}$ \\
\hline Agrail blue bag & 253.6 & $\mathrm{~g}$ & 283.4 & $\mathrm{e}$ & 12.68 & $\mathrm{~g}$ & 17.01 & e \\
\hline Plastic bag & 269.9 & $\mathrm{f}$ & 255.2 & $\mathrm{~h}$ & 13.49 & $\mathrm{f}$ & 15.31 & $\mathrm{~h}$ \\
\hline
\end{tabular}

Values have the same letter are not significantly different at 5\% level using Duncan's Test.

Table 4 and Fig. 1, 2, $3 \& 4$ revealed that, bagging with plastic bag gave the highest significant fruit cracking ( 8 and $10 \%)$ and sunburn irrespective the control (un-bagging) (25 and $24 \%$ ) compared to the other treatments in both seasons, respectively. While, the lowest significant fruit cracking (1 and $1 \%)$ and sun burnt fruits ( 2 and $2 \%$ ) were recorded in fruits bagged with prgmen in both seasons, respectively. Bagging the fruits may reduce sunburn because of the fruit protection from exposure to direct sun light. These results are in full agreement with those obtained by Wei et al. (2009), who reported that, bagging reduced cracking incidence significantly as compared to the control (5.1\% vs $32.8 \%$ ). Previous studies showed that, bagging decreases the incidence of fruit cracking. In this regard, the berry cracking rate of the non-bagging treatment was higher than $50 \%$, but the rate was $42.7 \%$ in berry treated with a white paper bag, $39.9 \%$ in treated with a yellow bag and $30 \%$ in fruits treated with a blue bag (Son and Lee, 2008). The fruit cracking rate of 'Daqingpitian' when bagged was $4.1 \%$ compared to $46 \%$ in the un-bagged control (Yuan, et al., 2010 and $\mathrm{Li}$, et al., 2011). With respect to the fruit sunburn, bagging Granny Smith apples with brown paper bags reduced sunburn fruits in both years (Walter and Mario, 1992).

Table 4, also showed that, un-bagged fruits are more susceptible to mechanical damage. While, mechanical fruit damage was not observed in fruits which bagged with both colours of paper bags (brown \& white) as well as prgmen bag. Bagging the fruits may reduce mechanical damage because of the fruit protection from branches scratching. Meanwhile, bagging fruits with agrail (white, red \& blue) and plastic bags reduce fruit mechanical damage.

Egypt. J. Hort. Vol. 41, No.2 (2014) 
TABLE 4. Effect of bagging type on fruit cracking (\%), sun burnt fruits (\%) and mechanical damage during 2011 \& 2012 seasons.

\begin{tabular}{|c|c|c|c|c|c|c|c|c|c|c|}
\hline \multirow{2}{*}{ Treatments } & \multicolumn{4}{|c|}{ Fruit cracking (\%) } & \multicolumn{4}{|c|}{ Sun-burnt fruits (\%) } & \multicolumn{2}{|c|}{ Mechanical damage } \\
\hline & 201 & & 201 & & 2011 & & & & 2011 & 2012 \\
\hline Control & 5.00 & $\mathrm{c}$ & 6.00 & $\mathrm{c}$ & 23.0 & $\mathrm{~b}$ & 25.0 & $\mathrm{a}$ & ++ & ++ \\
\hline Brown paper bag & 2.00 & $\mathrm{e}$ & 2.00 & $\mathrm{e}$ & 2.00 & $\mathrm{e}$ & 3.00 & $\mathrm{~g}$ & - & - \\
\hline White paper bag & 5.00 & $\mathrm{c}$ & 7.00 & $\mathrm{~b}$ & 2.00 & $\mathrm{e}$ & 5.00 & $\mathrm{f}$ & - & - \\
\hline Prgmen bag & 1.00 & $\mathrm{f}$ & 1.00 & $\mathrm{f}$ & 2.00 & $\mathrm{e}$ & 2.00 & $\mathrm{~h}$ & - & - \\
\hline Agrail white bag & 3.00 & d & 4.00 & d & 5.00 & $\mathrm{~d}$ & 10.0 & e & + & + \\
\hline Agrail red bag & 6.00 & $\mathrm{~b}$ & 7.00 & $\mathrm{~b}$ & 10.0 & $\mathrm{c}$ & 15.0 & $\mathrm{~d}$ & + & + \\
\hline Agrail blue bag & 6.00 & $\mathrm{~b}$ & 6.00 & $\mathrm{c}$ & 10.0 & $\mathrm{c}$ & 16.0 & $\mathrm{c}$ & + & + \\
\hline Plastic bag & 8.00 & $\mathrm{a}$ & 10.0 & $\mathrm{a}$ & 25.0 & $\mathrm{a}$ & 24.0 & $\mathrm{~b}$ & + & + \\
\hline
\end{tabular}

Values have the same letter are not significantly different at $5 \%$ level using Duncan's Test.

$(++)$ Higher mechanical damage, (+) lower mechanical damage, (-) no mechanical damage.

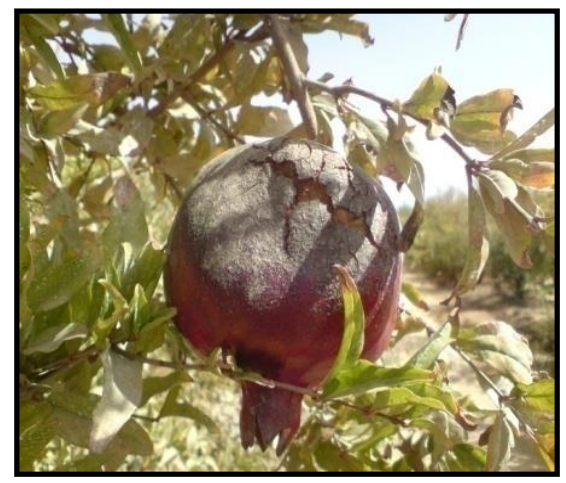

Fig. 1. Un-bagged fruit (control).

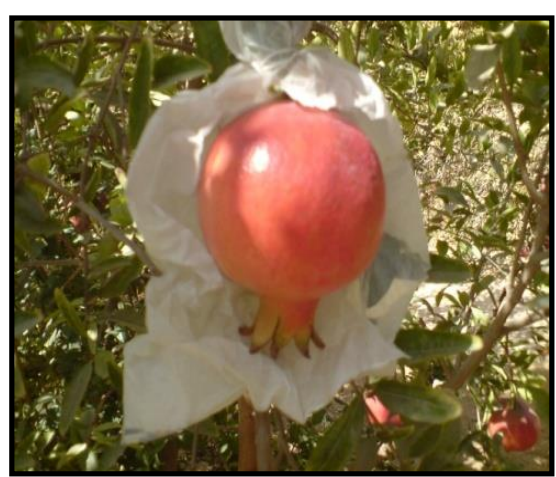

Fig. 3. Bagged fruit (prgmen).

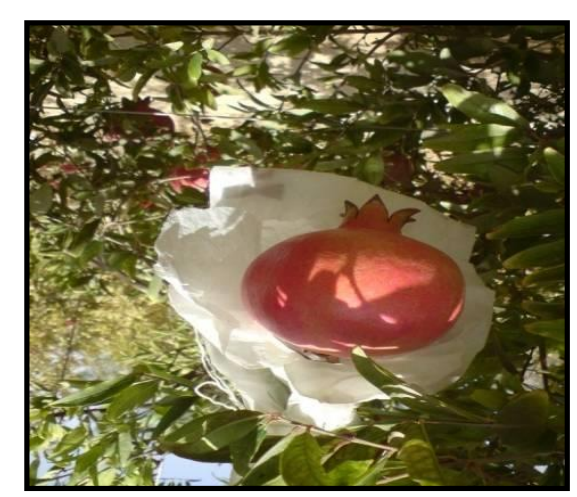

Fig. 2. Bagged fruit (prgmen).

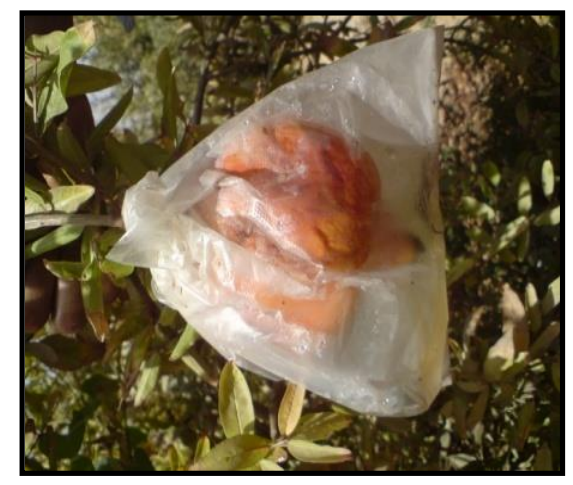

Fig. 4. Bagged fruit (plastic).

Egypt. J. Hort. Vol. 41, No.2 (2014) 
Table 5, showed that bagging with white paper bag had a significant effect on increasing fruit firmness compared to the other treatments. On the other hand, bagging fruits with plastic bag gave the lowest values. This was true in both seasons of study meanwhile, bagging with prgmen and brown paper followed by white paper significantly increased marketable fruits $(\%)$ than un-bagging fruits and other treatments. Moreover, plastic bag produced the least marketable fruits (\%). These results are in line with those obtained by Fenga et al. (2014), fruit firmness was slightly increased by bagging treatment. On the other hand, bagging of fruits did not affect firmness (Fallahi et al., 2001).

TABLE 5. Effect of bagging type on fruit firmness (kg) and marketable fruits (\%) during $2011 \& 2012$ seasons.

\begin{tabular}{|c|c|c|c|c|c|c|c|}
\hline \multirow{2}{*}{ Treatments } & \multicolumn{3}{|c|}{ Fruit firmness $\left(\mathrm{g} / \mathrm{cm}^{2}\right)$} & \multicolumn{4}{|c|}{ Marketable fruits (\%) } \\
\hline & 2011 & \multicolumn{2}{|c|}{2012} & \multicolumn{2}{|c|}{2011} & \multicolumn{2}{|c|}{2012} \\
\hline Control & $487.7 \quad \mathrm{~cd}$ & 470.0 & $\mathrm{c}$ & 72.0 & $\mathrm{~d}$ & 69.0 & $\mathrm{~d}$ \\
\hline Brown paper bag & 460.0 & 450.0 & $\mathrm{f}$ & 96.0 & $\mathrm{a}$ & 95.0 & $\mathrm{a}$ \\
\hline White paper bag & 550.0 & 480.0 & $\mathrm{a}$ & 93.0 & $\mathrm{~b}$ & 88.0 & $\mathrm{~b}$ \\
\hline Prgmen bag & 483.0 & 475.0 & $\mathrm{~b}$ & 97.0 & $\mathrm{a}$ & 97.0 & a \\
\hline Agrail white bag & 459.0 & 452.0 & $\mathrm{f}$ & 92.0 & $\mathrm{~b}$ & 86.0 & $\mathrm{~b}$ \\
\hline Agrail red bag & 530.0 & 460.0 & $\mathrm{e}$ & 84.0 & $\mathrm{c}$ & 78.0 & $\mathrm{c}$ \\
\hline Agrail blue bag & 510.0 & 466.0 & $\mathrm{~d}$ & 84.0 & $\mathrm{c}$ & 78.0 & $\mathrm{c}$ \\
\hline Plastic bag & 400.0 & 380.0 & $\mathrm{~g}$ & 67.0 & $\mathrm{e}$ & 66.0 & $\mathrm{e}$ \\
\hline
\end{tabular}

Values have the same letter are not significantly different at $5 \%$ level using Duncan's Test.

Table 6, showed that bagging with agrail blue bag had a significant effect on higher values of lightness (L) and (b) compared to the other treatments in both seasons. On the other hand, bagging fruits with plastic bag gave the lowest values. While, bagging with prgmen bag had a significant effect on increasing (a) value compared to the other treatments. These results agree with that obtained by $\mathrm{Wu}$ (2004) who reported that, the pomegranate fruits in bag had the best colour compared to the un-bagged fruits. Bagging fruit during development can improve colour at harvest (Bentley \& Viveros, 1992, Kitagawa et al., 1992, Byers \& Carbaugh, 1995 and Muchui et al., 2010). The bagged grapes presented higher values of lightness but lower values of redness and yellowness. Therefore, the non-bagged grapes were slightly darker, more red, with a higher colour intensity but were less blue than bagged samples (Antonia et al., 2007). Ju (1998) reported that, skin of un-bagged peach fruit had higher brightness (L-value) compared with that of bagged fruit. Also, Joyce et al. (1997) reported a lower percentage of blushes on the skin for bagged mangoes during fruit growth with non-perforated white paper bag opaque plastic bags than for non-bagged fruit or fruit bagged with paper bags. Litchi fruit were yellowish when bagged, and had higher scores for lightness (Fenga et al., 2014). Pre-harvest bagging of pears improved skin finish, resulting in a fruit with a more attractive light green colour, without reducing blush on the exposed side of the skin. In mangoes, the percentage of the

Egypt. J. Hort. Vol. 41, No.2 (2014) 
skin with red colour, and its intensity, decreased with increasing duration of fruit bagging (Hofman et al., 1997).

TABLE 6. Effects of bagging type on lightness (L), redness (a) and yellowness (b) during $2011 \& 2012$ seasons.

\begin{tabular}{|l|c|c|cc|cc|cc|cc|cc|}
\hline \multirow{2}{*}{ Treatments } & \multicolumn{4}{|c|}{ L } & \multicolumn{4}{c|}{ a } & \multicolumn{4}{c|}{ b } \\
\cline { 2 - 17 } & $\mathbf{2 0 1 1}$ & \multicolumn{2}{|c|}{$\mathbf{2 0 1 2}$} & $\mathbf{2 0 1 1}$ & $\mathbf{2 0 1 2}$ & $\mathbf{2 0 1 1}$ & \multicolumn{2}{|c|}{$\mathbf{2 0 1 2}$} \\
\hline Control & 43.33 & c & 44.00 & a & 40.13 & b & 43.00 & b & 26.40 & b & 32.12 & b \\
\hline Brown paper bag & 38.96 & d & 40.00 & ab & 40.12 & b & 42.70 & b & 18.44 & c & 24.00 & d \\
\hline White paper bag & 27.38 & f & 36.15 & bc & 29.02 & f & 30.12 & e & 10.56 & f & 15.14 & f \\
\hline Prgmen bag & 38.18 & d & 46.60 & a & 41.50 & a & 45.20 & a & 17.05 & d & 20.12 & e \\
\hline Agrail white bag & 35.12 & e & 43.12 & a & 36.92 & c & 39.12 & c & 16.25 & d & 27.12 & c \\
\hline Agrail red bag & 49.04 & b & 44.20 & a & 32.71 & e & 38.50 & c & 26.04 & b & 33.10 & b \\
\hline Agrail blue bag & 50.43 & a & 44.60 & a & 37.18 & c & 38.60 & c & 31.46 & a & 35.15 & a \\
\hline Plastic bag & 34.70 & e & 32.00 & c & 34.61 & d & 34.00 & d & 13.61 & e & 14.00 & f \\
\hline
\end{tabular}

Values have the same letter are not significantly different at $5 \%$ level using Duncan's Test.

\section{Fruit juice chemical composition}

Data in Table 7, clearly showed that, total soluble solids (TSS) increased significantly by bagging fruits with prgmen bag and un-bagged fruits. While, bagging with agrail blue and red as well as brown paper bags had a significant TSS reduction. On the other hand, bagging fruits with plastic bag gave the highest values of acidity compared with the other treatments. These results are in harmony with the findings of Bentley and Viveros (1992) who reported that, bagging fruits can increase soluble solids in apple but this is not always consistent. Also, bunch bagging treatments increased total soluble solids (TSS) and acidity concentration compared to the control (Mohamed et al., 2012). On the other hand, panicle bagging of lychee did not affect brix and acidity of the fruit at harvest (Tyas et al., 1998). Other researches indicated that, fruit bagging decreased soluble solids contents (Hong et al., 1999 and Huang et al., 2007). The total acidity was significantly higher in bagged 'Mutsu' than in non-bagged fruits (Arakawa et al., 1994 and Chen, et al., 2012).

TABLE 7. Effect of bagging type on total soluble solids and acidity (\%) during 2011 \& 2012 seasons.

\begin{tabular}{|l|cc|cc|cc|cc|}
\hline \multirow{2}{*}{\multicolumn{1}{|c|}{ Treatments }} & \multicolumn{4}{|c|}{ T.S.S } & \multicolumn{4}{c|}{ Acidity (\%) } \\
\cline { 2 - 10 } & \multicolumn{2}{|c|}{2011} & \multicolumn{2}{|c|}{$\mathbf{2 0 1 2}$} & \multicolumn{2}{c|}{$\mathbf{2 0 1 1}$} & \multicolumn{2}{c|}{$\mathbf{2 0 1 2}$} \\
\hline Control & 15.00 & $\mathrm{~b}$ & 16.00 & $\mathrm{a}$ & 1.23 & $\mathrm{~d}$ & 1.26 & $\mathrm{c}$ \\
\hline Brown paper bag & 12.00 & $\mathrm{e}$ & 13.00 & $\mathrm{~d}$ & 1.40 & $\mathrm{~b}$ & 1.44 & $\mathrm{~b}$ \\
\hline White paper bag & 13.00 & $\mathrm{~d}$ & 14.00 & $\mathrm{c}$ & 1.34 & $\mathrm{c}$ & 1.32 & $\mathrm{c}$ \\
\hline Prgmen bag & 16.00 & $\mathrm{a}$ & 15.00 & $\mathrm{~b}$ & 1.25 & $\mathrm{~d}$ & 1.27 & $\mathrm{c}$ \\
\hline Agrail white bag & 15.00 & $\mathrm{~b}$ & 15.00 & $\mathrm{~b}$ & 1.27 & $\mathrm{~d}$ & 1.29 & $\mathrm{c}$ \\
\hline Agrail red bag & 12.00 & $\mathrm{e}$ & 14.00 & $\mathrm{c}$ & 1.36 & $\mathrm{c}$ & 1.29 & $\mathrm{c}$ \\
\hline Agrail blue bag & 12.00 & $\mathrm{e}$ & 13.00 & $\mathrm{~d}$ & 1.35 & $\mathrm{c}$ & 1.31 & $\mathrm{c}$ \\
\hline Plastic bag & 14.00 & $\mathrm{c}$ & 14.00 & $\mathrm{c}$ & 1.65 & $\mathrm{a}$ & 1.62 & $\mathrm{a}$ \\
\hline
\end{tabular}

Egypt. J. Hort. Vol. 41, No.2 (2014) 
Values have the same letter are not significantly different at 5\% level using Duncan's Test.

The obtained results Table 8 indicated that, vitamin (C) and total juice anthocyanin increased significantly compared with the control and prgmen bag while, the lowest values were obtained from bagging fruit with plastic bag. It is known that, the processes of vitamin $\mathrm{C}$ and anthocyanin synthesis may need enough lights. In this respect, both the prgmen bag and the control (un-bagging) treatments provide sufficient light for the fruits, therefore, resulted in the best records. These results are in harmony with that obtained by Fenga et al., 2014, who reported that bagged fruits give the lowest concentration of anthocyanin. The anthocyanin content was highest in the non-bagging treatment (Son and Lee, 2008). On the other hand, Arakawa (1991 \& 1994) reported that bagged fruits produced higher levels of anthocyanin. Fruit bagging is an effective way to promote anthocyanin synthesis (Ritenour et al., 1997). With respect to the vitamin $\mathrm{C}$, bagged bunch increased vitamin $\mathrm{C}$ concentration (Mohamed et al., 2012). While, Chen et al., 2012 reported that, bagged fruits had decreased vitamin $\mathrm{C}$ contents of fruits compared with the non-bagged fruits. Also, $\mathrm{Su}$ et al. (2008) reported, bagging treatments had no great effects on vitamin C of mantianhong pear.

TABLE 8. Effect of bagging type on vitamin (C) $\mathrm{mg}$ ascorbic and total juice anthocyanin (\%) during 2011 \& 2012 seasons.

\begin{tabular}{|c|c|c|c|c|c|c|c|c|}
\hline \multirow[t]{2}{*}{ Treatments } & \multicolumn{4}{|c|}{$\begin{array}{c}\text { Vitamin }(C) \mathrm{mg} \text { ascorbic } \\
\text { acid } / 100 \mathrm{ml} \text { juice }\end{array}$} & \multicolumn{4}{|c|}{$\begin{array}{c}\text { Total juice anthocyanin } \\
(\%)\end{array}$} \\
\hline & \multicolumn{2}{|c|}{2011} & \multicolumn{2}{|c|}{2012} & \multicolumn{2}{|c|}{2011} & \multicolumn{2}{|c|}{2012} \\
\hline Control & 25.00 & $\mathrm{~b}$ & 27.00 & $\mathrm{a}$ & 0.30 & $\mathrm{a}$ & 0.31 & $\mathrm{a}$ \\
\hline Brown paper bag & 22.00 & $\mathrm{e}$ & 23.00 & $\mathrm{e}$ & 0.15 & $\mathrm{e}$ & 0.14 & $\mathrm{f}$ \\
\hline White paper bag & 24.00 & $\mathrm{c}$ & 24.00 & $\mathrm{~d}$ & 0.22 & $\mathrm{c}$ & 0.21 & $\mathrm{~d}$ \\
\hline Prgmen bag & 26.00 & $\mathrm{a}$ & 26.00 & $\mathrm{~b}$ & 0.29 & $\mathrm{a}$ & 0.28 & $\mathrm{~b}$ \\
\hline Agrail white bag & 23.00 & $\mathrm{~d}$ & 25.00 & $\mathrm{c}$ & 0.27 & $\mathrm{~b}$ & 0.24 & $\mathrm{c}$ \\
\hline Agrail red bag & 21.00 & $\mathrm{f}$ & 22.00 & $\mathrm{f}$ & 0.17 & $\mathrm{~d}$ & 0.16 & $\mathrm{~d}$ \\
\hline Agrail blue bag & 20.00 & $\mathrm{~g}$ & 19.00 & $\mathrm{~g}$ & 0.15 & $\mathrm{e}$ & 0.16 & $\mathrm{e}$ \\
\hline Plastic bag & 18.00 & $\mathrm{~h}$ & 16.00 & $\mathrm{~h}$ & 0.14 & $\mathrm{e}$ & 0.15 & $\mathrm{f}$ \\
\hline
\end{tabular}

Values have the same letter are not significantly different at 5\% level using Duncan's Test.

In both seasons of the study results in Table 9 clearly showed that, un-bagged fruits (control) and bagging fruits with prgmen bag were significantly the most effective compared to other treatments. While, the lowest values of TSS/acid ratio and total sugars (\%) were obtained when using plastic bags. These results are in line with those obtained by $\mathrm{Wu}$ (2004), he proved that, bagging pomegranate fruit treatments induced fruit total sugars percentage as compared with the control. Also, Noro et al. (1989) indicated that fructose content was higher in bagged than in nonbagged apple fruits. On the other hand, the total sugar contents were significantly decreased after bagging the fruits compared to the control (Su et al., 2008, Li et al., 2011 and Chen et al., 2012). While (Wei et al., 2009) reported that, bagging fruits had no significant effect on sugar contents.

Egypt. J. Hort. Vol. 41, No.2 (2014) 
TABLE 9. Effect of bagging type on tss/acid ratio and total sugars (\%) during 2011 \& 2012 seasons.

\begin{tabular}{|c|c|c|c|c|c|c|c|}
\hline \multirow{2}{*}{ Treatments } & \multicolumn{3}{|c|}{ TSS/acid ratio } & \multicolumn{4}{|c|}{ Total Sugars (\%) } \\
\hline & 2011 & \multicolumn{2}{|c|}{2012} & \multicolumn{2}{|c|}{2011} & \multicolumn{2}{|c|}{2012} \\
\hline Control & $12.20 \mathrm{~b}$ & 12.70 & $\mathrm{a}$ & 11.45 & a & 11.60 & $b$ \\
\hline Brown paper bag & 8.57 & 9.03 & $\mathrm{e}$ & 10.50 & d & 10.80 & e \\
\hline White paper bag & 9.70 & 10.61 & $\mathrm{c}$ & 11.30 & b & 11.20 & d \\
\hline Prgmen bag & 12.80 & 11.81 & $\mathrm{~b}$ & 11.41 & a & 11.70 & a \\
\hline Agrail white bag & $11.81 \quad \mathrm{c}$ & 11.63 & $\mathrm{~b}$ & 11.00 & $\mathrm{c}$ & 11.30 & $\mathrm{c}$ \\
\hline Agrail red bag & 8.82 & 10.85 & $\mathrm{c}$ & 10.00 & $\mathrm{f}$ & 10.25 & f \\
\hline Agrail blue bag & 8.89 & 9.92 & d & 10.25 & $\mathrm{e}$ & 10.26 & f \\
\hline Plastic bag & 8.48 & 8.64 & $\mathrm{f}$ & 10.00 & $\mathrm{f}$ & 10.20 & $\mathrm{~g}$ \\
\hline
\end{tabular}

Values have the same letter are not significantly different at 5\% level using Duncan's Test.

Finally, the economical comparative study between different bagging types clearly proved that, total cost/fed. ranged between (200 L.E.) in control (without bagging) to reach (2770 L.E.). When white, red \& blue agrail bags were used. However, the maximum yield (ton/fed.) and total income /fed recorded when prgmen bag was used, which in turn increased the net profit/fed as they recorded (5.96 ton/fed, $14900 \mathrm{LE} /$ fed \& $12550 \mathrm{LE} / \mathrm{fed}$ ), respectively. Whereas, the records were (4.29 ton/fed, $2150 \mathrm{LE} / \mathrm{fed} \& 1200 \mathrm{LE} / \mathrm{fed})$, respectively, when plastic bag was used.

TABLE 10. An economical comparative study between different bagging types.

\begin{tabular}{|l|c|c|c|c|c|c|c|c|}
\hline \multicolumn{1}{|c|}{ Treatments } & $\begin{array}{c}\text { Cost of } \\
\text { bagging/ } \\
\text { fed }\end{array}$ & $\begin{array}{c}\text { Cost of } \\
\text { fruit } \\
\text { bagging } \\
\text { process/ } \\
\text { fed. (LE) }\end{array}$ & $\begin{array}{c}\text { Cost of } \\
\text { fruits } \\
\text { worm } \\
\text { control } \\
\text { (LE) }\end{array}$ & $\begin{array}{c}\text { Total } \\
\text { cost } \\
\text { (LE) }\end{array}$ & $\begin{array}{c}\text { Value } \\
\text { of kg } \\
\text { fruit } \\
\text { (LE) }\end{array}$ & $\begin{array}{c}\text { Yield } \\
\text { ton/ } \\
\text { fed. }\end{array}$ & $\begin{array}{c}\text { Total } \\
\text { income/ } \\
\text { fed. } \\
\text { (LE) }\end{array}$ & $\begin{array}{c}\text { Net } \\
\text { profit } \\
\text { (LE) }\end{array}$ \\
\hline Control & - & - & 200 & 200 & 1 & 5.74 & 5740 & 5540 \\
\hline Brown paper bag & 980 & 480 & 50 & 1510 & 2 & 5.50 & 11000 & 9490 \\
\hline White paper bag & 980 & 480 & 50 & 1510 & 2 & 5.10 & 10200 & 8690 \\
\hline Prgmen bag & 1820 & 480 & 50 & 2350 & 2.50 & 5.96 & 14900 & 12550 \\
\hline Agrail white bag & 2240 & 480 & 50 & 2770 & 2.25 & 4.33 & 9740 & 6970 \\
\hline Agrail red bag & 2240 & 480 & 50 & 2770 & 2.25 & 4.65 & 10460 & 7690 \\
\hline Agrail blue bag & 2240 & 480 & 50 & 2770 & 2.25 & 4.76 & 10710 & 7940 \\
\hline Plastic bag & 420 & 480 & 50 & 950 & 0.50 & 4.29 & 2150 & 1200 \\
\hline
\end{tabular}




\section{Conclusion}

The best results with regard to the fruit quality of Wonderful pomegranate were obtained by bagged fruits with prgmen bag. The fruit disorders (sun burn and cracked fruit) were reduced. While, the fruit physical characteristics and fruit chemical compositions increased significantly. The prgmen bag gave the best results may be due to physicochemical characteristics of the bag i.e. transparent, light reflectance, air permeability and is not affected by a scratch branches. According to the obtained results we can recommend to use the prgmen bags with the pomegranate fruits in order to improve the farmer's net profit.

\section{References}

Abd El-Rhman, I.E. (2010) Physiological studies on cracking phenomena of pomegranates. J. Applied Sci. Res., 6(6), 696-703.

Antonia, J.S., Francisco, B., Francisco, M. and Angel, A. (2007) Effects of pre-harvest bagging on quality of black table grapes. World J. Agric. Sci., 3 (1), 32-38.

Arakawa, O. (1991) Effect of temperature on anthocyanin accumulation in apple fruit as affected by cultivar, stage of fruit ripening and bagging. J. Hort. Sci., 66 (6),763-768.

Arakawa, O., Uematsu, N. and Nakajima, H. (1994) Effect of bagging on fruit quality in apples. Bull. Fac. Agric. Hirosaki Univ., 57, 25-32.

Association of Official Agricultural Chemists (A.O.A.C.) (1985) "Official Methods of Analysis", $15^{\text {th }}$ ed. Published by A.O.A.C. Washington, D.C., USA.

Aviram, M. and Dornfeld, L. (2001) Pomegranate juice consumption inhibits serum angiotensin converting enzyme activity and reduces systolic blood pressure. Atherosclerosis, 158(1), 195-8.

Bentley, W.J. and Viveros, M. (1992) Brown-bagging Granny Smith apples on trees stops codling moth damage. California Agric., 46, 30-32.

Byers, R.E. and Carbaugh, D.H. (1995) Chemical, culture, and physiological factors influencing Stayman"e fruit cracking. Bull. Virginia Agric. Exp. Stn., 95: 1-33.

Chen, P.Z., Liu, Z., Jiang, B., Fan, Q., Wu, W., Qi, C. and Dai, X. (2012) Effects of bagging and foliar spray of NaHSO_3 on the yield and quality of Red Fuji apple. Guangdong Agric. Sci.08.

Dubois, M., Gilles, K.A., Hamilton, J.K., Rebers, P.A. and Smith, F. (1956) Colorimetric method for determination of sugars and related substances. Anual. Chem. 28, 350-356.

Duncan, D.B. (1955) Multiple range and multiple F. Tests biometrics, 11,1-24. 
Fallahi, E., Colt, W.M., Baird, C.R., Fallahi, B. and Chun, I.J. (2001) Influence of nitrogen and bagging on fruit quality and mineral concentrations of 'BC-2 Fuji' apple. Hort. Technology, 11, 462-466.

Fenga, B., Mingjun, L., Fengwangand, M. and Lailiang, C. (2014) The effects of bagging and debagging on external fruit quality, metabolites and the expression of anthocyanin biosynthetic genes in 'Jonagold' apple (MalusdomesticaBorkh.). Sci. Hort., 165(22), 123-131.

Gil, M.I., Tomàs-Barberàn, B., Hess-Pierce, D.M., Holcroft and Kader, A.A. (2000) Antioxidant activity of pomegranate juice and its relationship with phenolic composition and processing. J. Agric Food Chem., 48, 4581-9.

Guzman, E.C. (2004) Effect of fruit bagging on sanitation and pigmentation of six mango cultivars. Acta Hort., 645, 195-199.

Hofman, P.J., Smith, L.G., Joyce, D.C., Johnson, G.I. and Meburg, G.F. (1997) Bagging of mango (Mangiferaindica cv. 'Keitt') fruit influences fruit quality and mineral composition. Postharvest Biol. Technol., 12,83-91.

Hong, K.H., Kim, J.K., Jang, H.I., Choi, J.H., Han, J.W. and Kim, K.Y. (1999) Effect of paper sources for bagging on the appearance of fruit skin in Oriental pears (Pyrus pyrifolia Nakai cvs. Gamcheonbae and Yeongsanbae). J. Korean Soc. Hortic. Sci., 40, 554-558.

Hsia, C.L., Luh, B.S. and Chichester, C.O. (1965) Anthocyanins in freestone peaches. $J$. Food Sci., 30, 5-12.

Hu, G.B., Chen, D.C., Li, P., Ouyang, R., Gao, F.F., Wang, H.C. and Dong, J. (2001) Effects of bagging on fruit colration and phenylalaine ammonia lyase and polypehnol oxidase in 'Feizixiao'. Acta Hortic., 558, 273-278.

Huang, C.H., Chai, M.L., Pan, Z.M., Yu, B., Jiang, Z.M., Hu, J.L. and Teng, Y.W. (2007) Effects of bagging on fruit skin features and quality of Cuiguan pear cultivar. $J$. Fruit Sci., 24,747-751 (in Chinese).

Hudina, M., Stampar, F., Orazem, P., Petkovsek, M. and Veberic, R. (2012) Phenolic compounds profile, carbohydrates and external fruit quality of the 'concorde'pear (Pyruscommunis L.) after bagging. Can. J. Plant Sci., 92,1-9.

Jia, H.J., Araki, A. and Okamoto, G. (2005) Influence of fruit bagging on aroma volatiles and skin coloration of 'Hakuho' peach (PrunuspersicaBatsch). Postharvest Biol. Technol., 35, 61-68.

Johns, G.G. and Scott, K.J. (1989) Delayed harvesting of bananas with 'sealed' covers on bunches: 2. Effect on fruit yield and quality. Aust. J. Exp. Agric., 29,727-733.

Joyce, D.C., Beasleay, D.R. and Shorter, A.J. (1997) Effect of preharvest bagging on fruit calcium levels and storage and ripening characteristics of "Sensation" mangoes. Aust. J. Exp. Agric., 37, 383-389. 
Ju, Z. (1998) Fruit bagging, a useful method for studying anthocyanin synthesis and gene expression in apples. Sci. Hortic., 77, 155-164.

Kader, A.A. (2006) "Postharvest biology and technology of pomegranates", in Seeram, N.P. Schulman, R.N. and Heber D., Pomegranates: Ancient Roots to Modern Medicine, CRC Press Taylor \& Francis Group, Boca Raton, FL, 211-220.

Kitagawa, H., Manabe, K. and Esguerra, E.B. (1992) Bagging of fruit on the tree to control disease. Acta Hort., 321, 870-875.

LaRue, J.H. (1980) Growing Pomegranates in California. UCDA.Sci., Leaflet 2459.

Li, E.M., Shi, D.C., Xu, Y.H., Chen, F. and Zhai, H. (2008) Changing characteristics of temperature and humidity in different type bags for bagging apple and their effects on fruit appearance quality. Chin. J. Appl. Ecol., 19, 208-212.

Li, X., Ma, J., Shi, Y., Zhang, Q. and Zhou, X. (2011) Effect of type of bagging on quality and safety of pomegranate. Journal of Beijing Technology and Business University (Natural Sci. Ed.05.)

Maestre, J., Melgarejo, P., Tom'as-Barber'an FA and Garcia-Viguera, C. (2000) 'New food products derived from pomegranate', Options Medit, 42, 243-245.

McGuire, R.G. (1992) Reporting of objective color measurements. Hortic. Sci., 27,12541255.

Mohamed, A., Awada, B. and Adel, D. (2012) Gibberellic acid spray and bunch bagging increase bunch weight and improve fruit quality of 'Barhee' date palm cultivar under hot arid conditions. Sci. Hort., 138, 96-100.

Muchui, M.N., Mathooko, F.M., Njoroge, C.K., Kahangi, E.M., Onyango, C.A. and Kimani, E.M. (2010) Effect of perforated blue polyethylene bunch covers on selected postharvest quality parameters of tissue cultured bananas (Musa Spp.) cv. Williams in Central Kenya. J. Stored Prod. Postharvest Res., 1, 29-41.

Noro, S., Kudo, N. and Kitsuwa, T. (1989) Differences in sugar and organic acid contents between bagged and un-bagged fruits of the yellow apple cultivars, and the effect on development on anthocyanin. J. Jap. Soc. Hort. Sci., 58, 17-24.

Ritenour, M., Schrader, L., Kammereck, R., Donahue, R. and Edwards, G. (1997) Bag and liner color greatly affect apple temperature under full sunlight. Hort. Sci., 32, 272 .

Snedecor, G.W. and Cochran, W.G. (1980) "Statistical Methods", $7^{\text {th }}$ ed. Iowa State Univ. U.S.A. p.593.

Son, I.C. and Lee, C. H. (2008) The effects of bags with different light transmittance on the berry cracking of grape 'Kyoho'. Hort. Environ. Biotec., 49, 98-103.

Su, C.J., Zhang, C.I. and Zhang, W. (2008) Effect of bagging treatment on the main nutritional components in fruits of mantianhong and meirensu pear. J. of Henan Agri. Sci. 10 .

Egypt. J. Hort. Vol. 41, No.2 (2014) 
Thorp, T.G., Clearwater, M.J., Barnett, A.M., Martin, P.J., Blattmann, P.J. and Currie, M. B. (2007) 'Hort16A' fruit beak end softening and shriveling in California. Acta Hort., 753 (1), 389-396.

Tombesi, A., Antognozzi, E. and Palliotti, A. (1993) Influence of light exposure on characteristics and storage life of kiwifruit. N. Z. J. Crop Hort. Sci., 21, 87-92.

Tyas, J.A., Hofman, P.J., Underhill, S.J.R. and Bell, K.L. (1998) Fruit canopy position and panicle bagging affects yield and quality of 'Tai So' lychee. Sci. Hort., 72, 203 213.

Walter, J.B. and Mario, V. (1992) Brown bagging Granny Smith apples on trees stops codling moth damage. California Agriculture, 46(4), 30-32.

Wang, J.W., Chen, H.B., Zhou, Q. and Zhang, X.M. (2003) Effects of bagging on fruit quality in Litchi chinensis fruit and pesticide residues in it. Chinese J. Appl. Ecol., (in Chinese) 14, 710-712.

Wei, C.B., Sun, G.M., Li, S.P. and Xu, E.B. (2005) Effects of bagging on fruit quality of tropical fruits. J. South China Univ. Trop. Agr., (in Chinese) 11(3), 20-24.

Wei, H.Y., Xiao, C.Z., Jian, H.B., Gui, B.H., Hui, C.W. and Xu, M.H. (2009) Effects of bagging on fruit development and quality in cross-winter off-season longan. Sci. Hort., 120, 194-200.

Wei, Y.Z., Hu, F.C., Hu, G.B., Li, X.J., Huang, X.M. and Wang, H.C. (2011) Differential expression G. B. of anthocyanin biosynthetic genes in relation to anthocyanin accumulation in the pericarp of Litchi chinensisSonn. PloS One 6, e19455.

Witney, G.W., Kushad, M.M. and Barden J.A. (1991)Induction of bitter pit in apple. Sci. Hort., 47,173-176.

Wu, Z.J. (2004) Effect of bag encasing conditions on fruit quality of pomegranate. Agri. Sci. \& Technology - Hunan, 5 (2),17-19.

Xin, H.M. and Zhang, X.H. (2003) Influence of bagging on the fruit inclusion and endogenous hormones of Yali Pear variety. J. Fruit Sci. (in Chinese) 20(3), 233-235.

Yang, W., Zhu, X., Bu, J., Hua, G., Wanga, H. and Huang, X. (2009) Effects of bagging on fruit development and quality in cross-winter off-season longan. Sci. Hort., 120, 194-200.

Yuan, Z.H., Yin, Y.L., Feng, L.J., Zhao, X.Q., Hou, L.F. and Zhang, Y.X. (2010) Evaluation of pomegranate bagging and fruit cracking in shandong, china. International Society for Horticultural Science.

(Received 4 /8/2014; accepted 30/9/2014) 


\title{
تأثير نوع التكيس على تقليل عيوب ثمار الرمان وتحسين الجودة
}

\author{
محمد أبوالوفا أحمد \\ قسم بحوث الزينون وفاكهة المناطق الثبه جافة ـ معهد بحوث البساتين - مركز

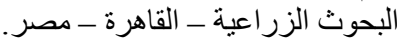

تم اجر اء الدراسة فى مزرعة خاصة بالطريق الصحر اوى فى محافظة البحبرة -

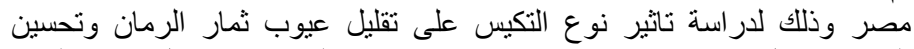

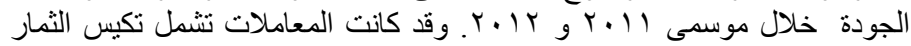

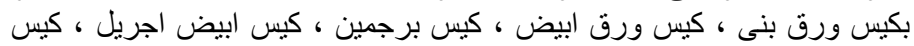

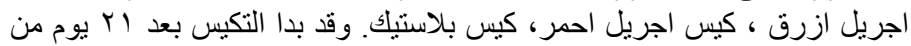

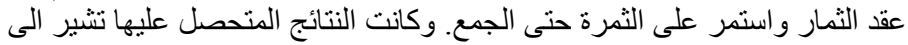

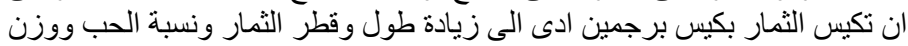

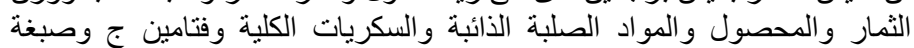

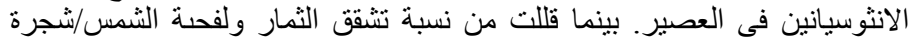

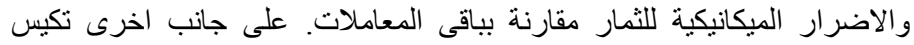

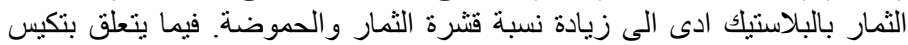

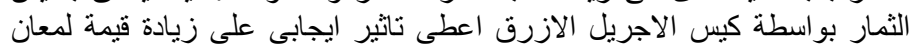

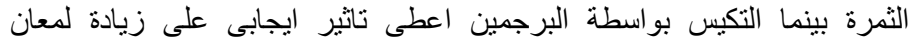

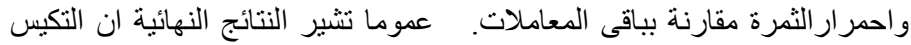

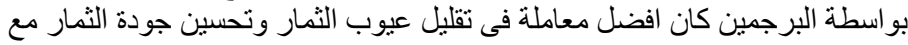

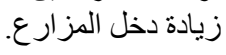

